\title{
Indikator Pembentuk Resiliensi Matematis Mahasiswa Prodi Pendidikan Matematika FKIP
}

\author{
Agusmanto JB Hutauruk ${ }^{1}$, Tutiarny Naibaho \\ ${ }^{1,2}$ Prodi Pendidikan Matematika FKIP Universitas HKBP Nommensen \\ a7hutauruk@uhn.ac.id
}

\begin{abstract}
Mathematical resilience is a mathematical ability that shows endurance and flexibility when studying and mastering mathematics. This research is a quantitative research that aims to analyze the variables forming the indicators of mathematical resilience ability in mathematics education study program students FKIP. The research subjects consisted of 178 students of Mathematics Education Study Program FKIP. All questionnaires were given to the questionnaire containing 33 variables forming mathematical resilience. Research data were analyzed using Factor Analysis. The results showed that 9 (nine) indicators could be formed as indicators for forming mathematical resilience of FKIP mathematics education study program students. Each of the 9 (nine) indicators is built by several variables which are the variables forming the mathematical resilience indicators.
\end{abstract}

Keyword: Mathematical Resilience, Factor Analysis

\begin{abstract}
Abstrak
Resiliensi matematis merupakan kemampuan matematis yang menunjukkan daya tahan dan daya lentur ketika mempelajari dan menguasai matematika. Penelitian ini merupakan penelitian kuantitatif yang bertujuan menganalisis variabel-variabel pembentuk indikator kemampuan resiliensi matematis pada mahasiswa prodi pendidikan matematika FKIP. Subjek penelitian terdiri dari mahasiswa prodi pendidikan matematia FKIP sebanyak 178 orang responden. Kepada seluruh responden diberikan kuisioner yang berisi variabel-variabel pembentuk resiliensi matematis sebanyak 33 statement. Data hasil penelitian dianalisis menggunakan Analisis Faktor. Hasil penelitian menunjukkan bahwa dapat dibentuk 9 (sembilan) indikator sebagai indikator pembentuk resiliensi matematis mahasiswa prodi pendidikan matematika FKIP. Masing-masing dari 9 (sembilan) indikator tersebut dibangun oleh beberapa variabel yang merupakan variabel pembentuk indikator resiliensi matematis tersebut
\end{abstract}

Kata Kunci: Resiliensi Matematis, Analisis Faktor.

\section{Pendahuluan}

Dalam proses belajar matematika akan ditemui berbagai kesulitan dalam kegiatan pembelajarannya, khususnya dalam usaha meningkatkan kemampuan matematis yang ingin dicapai, termasuk kesulitan yang sengaja dibuat untuk melatih dan membiasakan siswa agar terbiasa dalam aktifitas berpikir dan aktifitas memecahkan masalah (Hendrayana, 2015). Kesulitan dalam mempelajari dan menguasai matematika sangat beralasan karena matematika merupakan pelajaran yang menuntut siswa untuk berpikir logis, sistematis dan reflektif, serta membutuhkan usaha yang tekun, teliti dan sungguh-sungguh (NRC,2002; Reys dkk, 2009, dalam Hendrayana, 2015).

Untuk menghadapi kesulitan-kesuliatan yang didapat dalam proses pembelajaran matematika, diperlukan sifat resilien (daya lentur). Dalam proses pembelajaran, sebagian siswa memiliki pengalaman yang kurang menyenangkan tetapi tidak dapat dihindarkan. Setiap individu pernah mengalami kegagalan dan masa-masa yang penuh dengan kesulitan dalam proses pembelajarannya. 
Pengalaman tersebut tentu tidak dapat diubah, tetapi pengaruh negatif masa lalu dapat dikurangi atau bahkan dihilangkan. Untuk tujuan tersebut daya lentur (resilience) individu perlu dikembangkan. Pengembangan daya lentur sangat bermanfaat sebagai bekal dalam menghadapi situasi-situasi sulit yang tidak dapat dihindarkan.

Matematika sebagai salah satu subjek pembelajaran juga memerlukan resiliensi yang baik sehingga ilmu yang dipelajari dapat dimiliki seorang anak. Johnston-Wilder \& Lee (2010) mengusulkan suatu konsep resiliensi matematis sebagai suatu konsep yang penting yang diperoleh berdasarkan pengalaman matematis siswa yang cenderung "marah" dan berpotensi "gagal".

Menurut Johnston-Wilder, Lee, et.al. (2015), resiliensi matematis dapat dikembangkan pada siswa yang memiliki pengalaman "buruk" dengan matematika, dengan berfokus secara strategis dan eksplisit di lingkungan pendidikan formal dan informal. Dengan pengalaman matematis, siswa membangun kesadaran dan membangun manajemen resiko serta manajemen proses dalam pembelajaran matematika. Dalam konteks pembelajaran, resiliensi merupakan suatu konsep tentang kemampuan siswa dalam menghadapi masalah dan rintangan yang tampaknya tidak mungkin dapat dilaluinya dan tampak tidak dapat dilewati dengan hasil yang baik (Goodall \& Johnston-Wilder, 2015). Resiliensi dapat digambarkan sebagai "perjuangan" seorang siswa dalam menghadapi dan mengatasi hambatan (Waxman, Gray et.al., 2003). Resiliensi berkaitan dengan kemampuan afektif siswa untuk menghadapi, mengatasi, menjadi kuat ketika menghadapi rintangan dan hambatan dalam proses belajar.

Dalam kaitannya dengan pembelajaran matematika, Johnston-Wilder, et.al. (2014) mengutarakan bahwa pada dasarnya, resiliensi matematis terdiri dari 4 faktor: (1) keyakinan bahwa kemampuan otak dapat tumbuh, (2) pemahaman tentang penilaian pribadi setiap orang tentang matematika, (3) pemahaman tentang bagaimana bekerja matematis, dan (4) kesadaran atas dukungan dari rekan, orang yang lebih dewasa, ICT, internet, dll. Keempat faktor ini dapat menjadi dasar bertumbuh kembangnya kemampuan resiliensi matematis siswa ketika belajar matematika. Ashcraft (Goodall \& Johnston-Wilder, 2015) mengemukakan, konsep resiliensi matematis diperlukan dan harus dianggap sebagai bentuk "lawan" dari ketidakberdayaan terhadap matematika. Resiliensi matematis merupakan bagian dari ketahanan siswa untuk mengatasi kecemasan matematis yang melekat pada dirinya. Resiliensi matematis adalah kemampuan mempertahankan sikap afektif positif dalam kaitannya dengan pembelajaran matematika dalam mengatasi masalah matematik, serta mengembangkan keterampilan baru jika diperlukan.

Siswa dengan resiliensi matematis tidak menganggap matematika sebagai sesuatu yang "eksklusif" yang tidak mereka pahami namun dimengerti oleh orang lain. Siswa dengan kemampuan resiliensi matematis menganggap matematika sebagai "hak" mereka yang seharusnya mereka kuasai juga. Ketika siswa dengan resiliensi matematis mengalami kesulitan, ia akan tetap memiliki kepercayaan diri bahwa akhirnya ia akan mendapat hasil sukses. Ia sepenuhnya menyadari sumber daya yang ada untuk membantu dia, baik itu berasal dari keyakinannya pada diri sendiri, maupun pada sumber daya di luar dirinya, seperti lingkungan belajar, keluarga, dan masyarakat di sekelilingnya. Siswa dengan resiliensi mempertahankan sikap afektif positif dalam kaitannya dengan matematika. Secara signifikan, siswa mempertahankan kepercayaannya pada kemampuannya untuk mengatasi hambatan matematika, mengembangkan keterampilan baru jika diperlukan dan mendapatkan bantuan dan dukungan dari orang lain bila diperlukan. Pengembangan resiliensi matematis ini dapat dipengaruhi dan didukung dengan pembinaan (Johnston-Wilder, Lee et al., 2013b).

Thornton dan Statton (2012) mengidentifikasi lima aspek kunci dari resiliensi matematis: (1) memiliki mindset yang berkembang yang ditunjukkan melalui perilaku seperti belajar dari kesalahan; (2) memiliki metakognisi yang ditampilkan melalui kesediaan untuk merenungkan jawaban dan proses pemecahan masalah; (3) memiliki kemampuan adaptasi yang ditunjukkan melalui kemauan untuk mencoba strategi baru atau memulai lagi; (4) memiliki aspek interpersonal, dapat ditunjukkan dari usaha belajar untuk mengajukan pertanyaan yang cerdas karena 
adanya kesadaran atas kurangnya pengetahuan yang dimiliki; dan (5) memiliki sense of purpose yang ditunjukkan oleh keinginan siswa untuk mencari makna pembelajarannya.

Benard (Goodall \& Johnston-Wilder, 2015) mengemukakan empat ciri siswa yang resilien yatu (1) memiliki kompetensi sosial, (2) memiliki keterampilan pemecahan masalah, (3) memiliki kemandirian dan (4) sadar akan tujuan. Peatfield (2015) memberikan indikator seorang siswa memiliki resiliensi matematis yang kuat, yaitu :

1. Adanya rasa frustasi dan tidak nyaman ketika pertama kali diperhadapkan dengan suatu masalah matematis yang tidak dapat diselesaikan dengan mudah.

2. Munculnya ekspektasi bahwa ia dapat dan akan menyediakan waktu untuk memikirkan masalah tersebut sebelum menyelesaikannya.

3. Muncul keyakinan bahwa mereka dapat menyelesaikannya pada akhirnya.

4. Memiliki keinginan dan atau kebutuhan yang sangat kuat untuk menyelesaikan permasalahan matematis tersebut.

5. Mampu memilih strategi untuk menyelesaikannya (misalnya dengan diagram, bertanya teman apa yang harus dilakukan, dan sebagainya).

Jhonston-Wilder (2013a) mengemukakan empat faktor yang saling berkorelasi yang mengkonstruksi kemampuan resiliensi matematis:

1. Value, yaitu kepercayaan bahwa matematika adalah subjek yang berharga dan bernilai untuk dipelajari.

2. Struggle yaitu kesadaran dan pengakuan bahwa bergelut dengan matematika merupakan hal bersifat universal bahkan bagi orang-orang yang memiliki keterampilan matematika tingkat tinggi.

3. Growth, merupakan keyakinan bahwa semua orang dapat mengembangkan keterampilan matematika dan tidak percaya bahwa beberapa dilahirkan dengan atau tanpa kemampuan untuk belajar matematika.

4. Resiliensce, merupakan sebuah orientasi untuk menghasilkan respon positif ketika menghadapi situasi negatif atau kesulitan dalam belajar matematika.

Menurut Hutauruk (2017) secara umum terdapat empat indikator resiliensi matematis yaitu:

1. memiliki keyakinan bahwa matematika sebagai sesuatu yang berharga dan layak untuk ditekuni dan dipelajari (value ilmu matematika)

2. memiliki kemauan dan kegigihan dalam mempelajari matematika, walaupun mengalami kesulitan, hambatan dan tantangan (kegigihan).

3. memiliki keyakinan pada diri sendiri bahwa mampu mempelajari dan menguasai matematika, baik berdasarkan pemahaman atas matematika, kemampuan menciptakan strategi, bantuan alat dan orang lain, dan juga pengalaman yang dibangun (efikasi diri)

4. memiliki sifat bertahan, tidak pantang menyerah, serta selalu memberi respon positif dalam belajar matematika (resiliensi)

Dari keempat indikator tersebut, akan disusun sub-sub indikator yang akan menjadi bagian dari instrument penelitian untuk melihat faktor yang paling kuat dalam membentuk indikator pembentuk resiliensi matematis.

\section{Metode Penelitian}

Penelitian ini merupakan penelitian kuantitatif dengan teknik analisis data menggunakan teknik analisis faktor jenis konfirmatori (Confirmatory Factor Analysis = CFA). Analisis CFA bertujuan untuk mencari sejumlah variable indikator yang membentuk variabel yang tidak terukur langsung berdasarkan landasan teori. Proses analisis data akan menggunakan aplikasi SPSS. Subjek penelitian ini adalah seluruh mahasiswa prodi pendidikan matematika di FKIP Universitas HKBP Nommensen, sehingga penelitian ini dapat dikatakan merupakan penelitian populasi. Hal ini 
dikarenakan analisis data dengan CFA sebaiknya mempergunakan subjek penelitian dalam jumlah yang besar.

Instrumen yang dipergunakan dalam penelitian ini adalah Skala Resilliensi Matematis yang terdiri dari beberapa pernyataan yang menjadi sub indikator pembentuk variabel indikator resiliensi matematis. Skala Resiliensi Matematis tersebut menggunakan skala sikap Likert untuk mengungkap sikap setuju dan tidak setuju terhadap faktor-faktor yang mempengaruhi resiliensi matematis. Teknik analisis data menggunakan teknik CFA dengan berbantuan aplikasi SPSS. Beberapa asumsi dasar yang harus dipenuhi dalam analisis faktor adalah sebagai berikut:

1. Asumsi Normalitas Data

2. Asumsi Analisis Faktor yang pertama adalah: Uji Determinant of Correlation Matrix. Matrik korelasi dikatakan antar variabel saling terkait apabila determinan bernilai mendekati nilai 0 .

3. Asumsi Analisis Faktor yang kedua adalah: Kaiser Meyer Olkin Measure of Sampling (KMO) adalah indek perbandingan jarak antara koefisien korelasi dengan koefisien korelasi parsialnya. Jika jumlah kuadrat koefisen korelasi parsial di antara seluruh pasangan variabel bernilai kecil jika dibandingkan dengan jumlah kuadrat koefisien korelasi, maka akan menghasilkan nilai KMO mendekati 1. Nilai KMO dianggap mencukupi jika lebih dari 0,5.

4. Asumsi Analisis Faktor yang ketiga adalah: Bartlett Test of Sphericity. Bartlett Test of Spehricity memenuhi persyaratan jika signifikansi di bawah 0,05 (5\%).

5. Pengujian seluruh matriks korelasi (korelasi antar variabel), yang diukur dengan besaran Bartlett Test of Sphericity atau Measure Sampling Adequacy (MSA). Pengujian ini mengharuskan adanya korelasi yang signifikan di antara paling sedikit beberapa variabel, dalam hal ini keempat variabel sebagai indikator akan diukur nilai MSA nya. Variabel yang memenuhi persyaratan MSA yaitu di atas 0,5.

Selanjutnya setelah semua asumsi dasar Analisis Faktor dipenuhi, maka analisis data sebagai dasar pengambilan keputusan penelitian dengan CFA dapat dilakukan dengan memperhatikan hal-hal di bawah ini:

1. Nilai Communalities menunjukkan seberapa besar sebuah variabel dapat menjelaskan faktor.

2. Total Variance Explained di bawah ini berguna untuk menentukan berapakah faktor yang mungkin dapat dibentuk yakni yang memiliki nilai eigenvalues $>1$.

3. Factor Loading melakukan penentuan masing-masing variabel akan masuk ke dalam faktor mana dengan melihat tabel component matix, rotated component matrix dan tabel Component Transformation Matrix.

4. Menentukan faktor skor. Dari skor tersebut dapat dilakukan analisis lanjutan, misal analisis regresi linear, analisis diskriminan atau analisis lainnya.

\section{Hasil Penelitian dan Pembahasan}

\subsection{Hasil Penelitian}

Penelitian untuk menentukan indikator pembentuk resiliensi matematis mahasiswa prodi pendidikan matematika dimulai dengan menyusun sejumlah variabel yang akan membentuk komponen faktor resiliensi matematis. Variabel-variabel tersebut disadur dari hasil penelitian Hutauruk (2017) dan Kooken et.al. (2015) dan disusun ke dalam kuisioner untuk diisi oleh responden. Sebanyak 33 pernyataan disusun dalam kuisioner dan diberikan kepada 178 responden yang terdiri dari mahasiswa-mahasiswa program studi pendidikan matematika dari semua tingkat semester. Setelah kuisioner diberikan kepada responden selanjutnya diperoleh data variabel pembentuk resiliensi matematis. Data tersebut kemudian dianalisis dengan analisis faktor menggunakan software SPSS. 
Sebelum melakukan uji analisis faktor terlebih dahulu dilakukan uji asumsi sebagai syarat melanjutkan analisis faktor. Uji asumsi yang pertama adalah uji Determinant of Correlation Matrix. Matriks korelasi dikatakan menunjukkan bahwa antar variable saling terkait apabila determinan bernilai mendekati nol. Hasil uji Determinan menunjukkan bahwa nilai determinan sebesar 1.11 E-0.007. Dengan demikian dapat dikatakan bahwa variabel-variabel pembentuk resiliensi matematis saling terkait.

Uji asumsi selanjutnya adalah uji Kaiser Meyer Olkin Measure of Sampling (KMO) dan Bartlett Test of Sphericity (test Bartlett). Pada uji ini, nilai KMO dianggap mencukupi jika lebih dari 0.5, serta uji Bartlett Test of Spehricity memenuhi persyaratan jika signifikansi di bawah 0,05 (5\%). Hasil uji ditunjukkan pada tabel di bawah ini.

Tabel 4.2. Uji KMO dan Uj Bartlett

KMO and Bartlett's Test

\begin{tabular}{|ll|r|}
\hline Kaiser-Meyer-Olkin Measure of Sampling Adequacy. & .854 \\
Bartlett's Test of & Approx. Chi-Square & 2644.333 \\
Sphericity & df & 528 \\
& Sig. & .000 \\
\hline
\end{tabular}

Tabel di atas menunjukkan bahwa nilai KMO adalah $0.854>0.5$, dan uji Bartlett memiliki nilai sig. $0.000<0.05$. Dengan demikian uji asumsi KMO dan uji Bartlett memenuhi syarat dilakukannya analisis faktor.

Selanjutnya dilakukan uji Measures of Sampling Adequacy (MSA). Uji ini bertujuan untuk menentukan variabel-variabel mana yang memenuhi syarat untuk dimasukkan dalam analisis faktor. Variabel yang dapat dipergunakan dalam analisis faktor pembentuk resiliensi matematis adalah variabel yang memiliki MSA $>0.5$. Jika terdapat variabel yang memiliki nilau MSA $<0.5$, maka variabel tersebut dibuang, dan uji Asumsi diulang lagi dari awal. Hasil uji MSA menunjukkan bahwa setiap variabel memiliki nilai MSA > 0.5, artinya bahwa setiap variabel dapat diikutsertakan dalan analisis faktor selanjutnya untuk menentukan indikator pembentuk resiliensi matematis.

Berdasarkan hasil uji asumsi di atas, tampak bahwa analisis faktor dapat dilanjutkan ke tahap berikutnya. Tahap analisis faktor diawali dengan analisis communalities. Analisis ini bertujuan untuk menunjukkan seberapa besar sebuah variabel dapat menjelaskan faktor. Nilai extraction > 0,5 bermakna variabel tersebut dapat menjelaskan faktor. Hasil analisis communalities ditunjukkan oleh tabel berikut ini.

Tabel.4.4. Analisis Communalities

\begin{tabular}{|c|c|c|c|}
\hline & & Initial & Extraction \\
\hline Value 1 & & 1.000 & .747 \\
\hline Value 2 & & 1.000 & .539 \\
\hline Value 3 & & 1.000 & 789 \\
\hline Value 4 & & 1.000 & .663 \\
\hline Value 5 & & 1.000 & .728 \\
\hline Walue 6 & & 1.000 & .623 \\
\hline Value $T$ & & 1.000 & .616 \\
\hline Value 8 & & 1.000 & .707 \\
\hline Value 9 & & 1.000 & .673 \\
\hline strugale 1 & & 1.000 & .761 \\
\hline Struggle $z$ & & 1.000 & .746 \\
\hline Struggle 3 & & 1.000 & .627 \\
\hline Struggle 4 & & 1.000 & .701 \\
\hline Strugale 5 & & 1.000 & .689 \\
\hline Struggle 6 & & 1.000 & .694 \\
\hline Struggle 7 & & 1.000 & .732 \\
\hline Struggle 8 & & 1.000 & .633 \\
\hline Grawth 1 & & 1.000 & .669 \\
\hline Grawth 2 & & 1.000 & .666 \\
\hline Growth 3 & & 1.000 & .639 \\
\hline Grounth 4 & & 1.000 & .660 \\
\hline Growth 5 & & 1.000 & .590 \\
\hline Grounth 6 & & 1.000 & .635 \\
\hline Growth 7 & & 1.000 & .566 \\
\hline Grawth 8 & & 1.000 & .677 \\
\hline Resilience 1 & 1 & 1.000 & .600 \\
\hline Resilience & $z$ & 1.000 & .682 \\
\hline Resilience & 3 & 1.000 & .751 \\
\hline Resilience 4 & 4 & 1.000 & .768 \\
\hline Resiliences & 5 & 1.000 & .579 \\
\hline Resilience & 6 & 1.000 & .687 \\
\hline Resilience? & 7 & 1.000 & .595 \\
\hline Resilience & 8 & 1000 & 664 \\
\hline
\end{tabular}


Tampak bahwa dari nilai extraction pada tabel tersebut, setiap variabel memiliki nilai lebih dari 0.5 , sehingga dapat dikatakan bahwa setiap variabel tersebut dapat menjelaskan faktor pembentuk resiliensi matematis. Selanjutnya dilakukan analisis eigenvalues untuk menentukan berapakah faktor yang mungkin dapat dibentuk dari semua variabel yang ada. Faktor yang terbentuk merupakan faktor dengan nilai pada kolom Initial Eigenvalues dengan nilai eigenvalues lebih atau sama dengan 1. Berikut ini adalah tabel yang menunjukkan faktor pembentu resiliensi matematis yang dihasilkan.

Tabel 4.5. Faktor Pembentuk Resiliensi Matematis

\begin{tabular}{|c|c|c|c|c|c|c|c|c|c|}
\hline \multirow[b]{2}{*}{ Component } & \multicolumn{3}{|c|}{ Initial Eigenvalues } & \multicolumn{3}{|c|}{ Extraction Sums of Squared Loadings } & \multicolumn{3}{|c|}{ Rotation Sums of Squared Loadings } \\
\hline & Total & $\%$ of Variance & Cumulative \% & Total & \% of Variance & Cumulative \% & Total & \% of Variance & Cumulative \% \\
\hline 1 & 8.983 & 27.220 & 27.220 & 8.983 & 27.220 & 27.220 & 3.824 & 11.587 & 11.587 \\
\hline 2 & 2.879 & 8.725 & 35.945 & 2.879 & 8.725 & 35.945 & 3.276 & 9.927 & 21.513 \\
\hline 3 & 2.533 & 7.676 & 43.621 & 2.533 & 7.676 & 43.621 & 2.956 & 8.957 & 30.470 \\
\hline 4 & 1.626 & 4.927 & 48.548 & 1.626 & 4.927 & 48.548 & 2.755 & 8.350 & 38.820 \\
\hline 5 & 1.397 & 4.234 & 52.782 & 1.397 & 4.234 & 52.782 & 2.125 & 6.440 & 45.260 \\
\hline 6 & 1.315 & 3.986 & 56.768 & 1.315 & 3.986 & 56.768 & 2.105 & 6.380 & 51.640 \\
\hline 7 & 1.244 & 3.769 & 60.537 & 1.244 & 3.769 & 60.537 & 2.085 & 6.318 & 57.958 \\
\hline 8 & 1.103 & 3.341 & 63.878 & 1.103 & 3.341 & 63.878 & 1.498 & 4.540 & 62.498 \\
\hline 9 & 1.015 & 3.075 & 66.953 & 1.015 & 3.075 & 66.953 & 1.470 & 4.455 & 66.953 \\
\hline 10 & .964 & 2.922 & 69.875 & & & & & & \\
\hline 11 & .817 & 2.477 & 72.352 & & & & & & \\
\hline 12 & .779 & 2.359 & 74.711 & & & & & & \\
\hline 13 & .673 & 2.040 & 76.752 & & & & & & \\
\hline 14 & .651 & 1.973 & 78.725 & & & & & & \\
\hline 15 & .631 & 1.913 & 80.638 & & & & & & \\
\hline 16 & .596 & 1.806 & 82.444 & & & & & & \\
\hline 17 & .565 & 1.712 & 84.156 & & & & & & \\
\hline 18 & .516 & 1.565 & 85.721 & & & & & & \\
\hline 19 & .498 & 1.508 & 87.229 & & & & & & \\
\hline 20 & .452 & 1.370 & 88.599 & & & & & & \\
\hline 21 & .430 & 1.303 & 89.901 & & & & & & \\
\hline 22 & .399 & 1.208 & 91.109 & & & & & & \\
\hline 23 & .354 & 1.074 & 92.183 & & & & & & \\
\hline 24 & .340 & 1.030 & 93.213 & & & & & & \\
\hline 25 & .325 & .985 & 94.198 & & & & & & \\
\hline 26 & .308 & .932 & 95.130 & & & & & & \\
\hline 27 & .283 & .857 & 95.988 & & & & & & \\
\hline 28 & .268 & .813 & 96.800 & & & & & & \\
\hline 29 & .252 & .763 & 97.563 & & & & & & \\
\hline 30 & .245 & .743 & 98.306 & & & & & & \\
\hline 31 & .210 & .637 & 98.943 & & & & & & \\
\hline 32 & .185 & .560 & 99.503 & & & & & & \\
\hline 33 & .164 & .497 & 100.000 & & & & & & \\
\hline
\end{tabular}

Extraction Method: Principal Component Analysis. 
Pada tabel $4.5 \mathrm{di}$ atas, terlihat bahwa dari keseluruhan variabel yang dianalisis, terbentuk 9 (sembilan) faktor yang memiliki nilai eigenvalues $>1$. Dengan demikian dapat dikatakan terdapat 9 faktor utama pembentuk kemampuan resiliensi matematis. Dengan memperhatikan nilai cumulative $\%$ pada tabel di atas juga dapat dikatakan bahwa kesembilan faktor yang terbentuk tersebut menjelaskan kemampuan resiliensi matematis sebesar $66.953 \%$, sedangkan sisanya dijelaskan oleh faktor lain.

Setelah dapat ditentukan bahwa terdapat 9 (Sembilan) faktor pembentuk resiliensi matematis, maka selanjutnya dilakukan analisis factor loading untuk menentukan masing-masing variabel akan masuk ke dalam faktor yang mana. Analisis factor loading tersebut dilakukan dengan melihat nilai korelasi terbesar untuk setiap faktor yang terbentuk, yang ditunjukkan pada tabel di bawah ini. 
Tabel 4.6. Rotated Component Matrix

Rotated Component Matrix

\begin{tabular}{|c|c|c|c|c|c|c|c|c|c|}
\hline & & & & & nponen & & & & \\
\hline & 1 & 2 & 3 & 4 & 5 & 6 & 7 & 8 & 9 \\
\hline Resilience 2 & .781 & .091 & .005 & -.180 & .013 & .039 & .114 & .126 & .014 \\
\hline Resilience 3 & .764 & .147 & .235 & -.029 & .149 & .120 & .185 & -.078 & .108 \\
\hline Resilience 4 & .742 & .008 & .426 & -.001 & -.100 & .115 & .106 & -.042 & .013 \\
\hline Growth 8 & .615 & .327 & .135 & .040 & .243 & .130 & .063 & .294 & .083 \\
\hline Resilience 5 & .583 & .372 & .234 & .005 & .011 & .013 & .092 & .079 & .177 \\
\hline Resilience 1 & .520 & .456 & .228 & -.052 & .112 & .077 & .032 & .124 & .181 \\
\hline Resilience 7 & .479 & .301 & .010 & -.081 & -.004 & -.048 & .136 & .180 & .463 \\
\hline Value 8 & .175 & .757 & .175 & -.151 & .007 & .111 & .172 & -.086 & -.022 \\
\hline Value 9 & .162 & .705 & .098 & -.132 & .090 & .171 & -.147 & .071 & .243 \\
\hline Value 7 & .261 & .655 & -.004 & -.143 & .003 & .134 & .132 & .235 & .086 \\
\hline Value 6 & .017 & .583 & .176 & -.197 & .041 & .449 & .083 & .017 & -.054 \\
\hline Value 2 & .356 & .456 & .035 & -.093 & -.144 & .157 & .134 & .362 & .021 \\
\hline Struggle 4 & .133 & .095 & .760 & -.068 & .079 & -.055 & .259 & .038 & .121 \\
\hline Struggle 5 & .148 & .236 & .756 & -.051 & .135 & -.012 & -.089 & .027 & .103 \\
\hline Growth 2 & .177 & .162 & .659 & -.027 & -.031 & .052 & .318 & .260 & -.035 \\
\hline Growth 1 & .396 & .029 & .611 & .057 & .063 & .154 & .297 & .107 & -.091 \\
\hline Growth 5 & .170 & -.041 & .545 & -.189 & .351 & .199 & -.074 & .030 & .242 \\
\hline Growth 6 & -.027 & -.133 & -.046 & .770 & .075 & -.042 & .012 & .041 & -.111 \\
\hline Resilience 8 & -.161 & -.008 & .053 & .759 & -.185 & -.062 & -.111 & -.091 & -.023 \\
\hline Growth 4 & .093 & -.122 & -.007 & .737 & -.225 & .050 & .073 & -.081 & -.168 \\
\hline Growth 3 & -.055 & -.233 & -.175 & .721 & -.137 & -.098 & -.003 & .052 & .014 \\
\hline Growth 7 & .218 & -.250 & .041 & -.403 & .358 & .303 & .242 & .062 & .096 \\
\hline Struggle 7 & .063 & .063 & .114 & -.156 & .803 & -.055 & .075 & -.071 & .168 \\
\hline Struggle 6 & .035 & .014 & .101 & -.220 & .777 & -.102 & .031 & .085 & -.110 \\
\hline Value 3 & .107 & .154 & .003 & -.038 & -.029 & .855 & .037 & .120 & .070 \\
\hline Value 5 & .142 & .299 & .035 & -.097 & -.128 & .764 & .055 & .001 & .066 \\
\hline Struggle 2 & .157 & .119 & .095 & -.010 & .084 & .086 & .820 & -.004 & .105 \\
\hline Struggle 1 & .183 & .033 & .259 & -.050 & .023 & -.050 & .781 & .096 & .183 \\
\hline Struggle 3 & .332 & .413 & .168 & .030 & .293 & .188 & .439 & -.004 & -.059 \\
\hline Value 1 & .154 & .044 & .128 & -.055 & .001 & .029 & .084 & .832 & .032 \\
\hline Value 4 & .014 & .285 & .230 & .044 & .181 & .443 & -.109 & .534 & .006 \\
\hline Resilience 6 & .194 & .038 & .138 & -.259 & -.036 & .101 & .151 & -.068 & .723 \\
\hline Struggle 8 & .024 & .162 & .123 & -.052 & .457 & .080 & .161 & .104 & .580 \\
\hline
\end{tabular}

Pada tabel 4.6 di atas, tampak nilai korelasi yang terbentuk oleh masing-masing variabel dengan faktor yang terbentuk. Dari nilai korelasi tersebut, dapat disusun 9 (sembilan) faktor dengan variabel-variabel masing-masing yakni faktor 1 terdiri dari 7 variabel pembentuk, faktor 2 terdiri dari 5 variabel pembentuk, faktor 3 terdiri dari 5 variabel pembentuk, faktor 4 terdiri dari 4 variabel pembentuk, faktor 5 terdiri dari 3 variabel pembentuk, faktor 6 terdiri dari 2 variabel pembentuk, faktor 7 terdiri dari 3 variabel pembentuk, serta faktor 8 dan 9 masing-masing terdiri dari 2 variabel pembentuk.

\subsection{Pembahasan}

Hasil penelitian yang telah diperoleh dari analisis faktor berdasarkan penjabaran data di atas selanjutnya akan menjelaskan mengenai indikator pembentuk kemampuan resiliensi matematis pada mahasiswa prodi pendidikan matematika. Secara rinci setiap faktor resiliensi matematis yang terbentuk beserta variabel pembentuknya dituliskan dalam tabel berikut 
SEPREN: Journal of Mathematics Education and Applied Vol. 01, No.02, 78-91 
Tabel 4.7. Faktor Resiliensi Matematis beserta Variabel Pembentuknya

\begin{tabular}{|c|c|}
\hline Faktor & Variabel Pembentuk Resiliensi Matematis \\
\hline \multirow{7}{*}{1} & $\begin{array}{l}\text { Saya percaya bahwa saya mampu mengembangkan pengetahuan tentang } \\
\text { matematika }\end{array}$ \\
\hline & $\begin{array}{l}\text { Ketika menggunakan cara yang salah pada saat mempelajari matematika, saya } \\
\text { mengetahui bagaimana beradaptasi dan mempelajari kembali dengan cara yang } \\
\text { benar. }\end{array}$ \\
\hline & $\begin{array}{l}\text { Terkadang saya berkecil hati ketika mengalami kesulitan dalam mempelajari } \\
\text { matematika, namun saya bangkit kembali. }\end{array}$ \\
\hline & $\begin{array}{l}\text { Saya mencari cara/strategi yang lain ketika mengalami kebuntuan dalam } \\
\text { memecahkan masalah matematika. }\end{array}$ \\
\hline & $\begin{array}{l}\text { Ketika gagal atau memperoleh hasil yang kurang baik pada tes matematika, saya } \\
\text { menyadari bahwa saya harus belajar lebih keras. }\end{array}$ \\
\hline & $\begin{array}{l}\text { Saya berjuang lebih keras dalam mempelajari matematika, hingga saya mampu } \\
\text { menguasainya. }\end{array}$ \\
\hline & $\begin{array}{l}\text { Walaupun terkadang merasa bingung ketika belajar matematika, saya tetap } \\
\text { bertahan }\end{array}$ \\
\hline \multirow{5}{*}{2} & Matematika berguna dalam kegiatan saya sehari-hari. \\
\hline & $\begin{array}{l}\text { Orang yang pandai matematika memiliki lebih banyak kesempatan daripada } \\
\text { mereka yang tidak pandai matematika. }\end{array}$ \\
\hline & Berpikir matematis dapat membantu saya dalam hal-hal yang penting. \\
\hline & Keberhasilan dalam hidup akan sulit dicapai tanpa ilmu matematika. \\
\hline & $\begin{array}{l}\text { Matematika mengembangkan kemampuan berpikir yang baik, yang mendukung } \\
\text { kesuksesan di segala bidang karir }\end{array}$ \\
\hline \multirow{5}{*}{3} & $\begin{array}{l}\text { Semua orang termasuk saya, pernah membuat kesalahan pada saat belajar } \\
\text { matematika. }\end{array}$ \\
\hline & $\begin{array}{l}\text { "Mencoret-coret" di kertas buram untuk mencari solusi suatu masalah } \\
\text { matematika merupakan hal yang wajar. }\end{array}$ \\
\hline & Saya dapat menjadi lebih baik dalam matematika jika terus mencoba. \\
\hline & Matematika dapat dipelajari oleh siapa saja. \\
\hline & Ada orang yang kemampuannya baik dalam matematika dan ada yang tidak. \\
\hline \multirow{4}{*}{4} & $\begin{array}{l}\text { Seseorang yang tidak memiliki bakat matematika tidak akan mampu belajar } \\
\text { banyak tentang matematika. }\end{array}$ \\
\hline & $\begin{array}{l}\text { Tidak ada yang dapat saya lakukan untuk mengubah ketidak-pandaian saya } \\
\text { dalam matematika. }\end{array}$ \\
\hline & Saya percaya kemampuan matematika setiap orang merupakan faktor genetik \\
\hline & $\begin{array}{l}\text { Ketika hasil tugas atau hasil tes matematika yang saya dapatkan tidak sesuai } \\
\text { dengan harapan, artinya hanya sebatas itu kemampuan saya. }\end{array}$ \\
\hline \multirow{3}{*}{5} & Saya memiliki kemungkinan gagal pada tes matematika yang sulit. \\
\hline & Guru matematika terkadang bingung dengan masalah matematika. \\
\hline & Tidak setiap orang dapat memecahkan masalah matematika. \\
\hline \multirow{2}{*}{6} & $\begin{array}{l}\text { Pengetahuan matematika yang saya miliki sangat membantu saya ketika } \\
\text { mempelajari ilmu atau topik apapun. }\end{array}$ \\
\hline & $\begin{array}{l}\text { Memiliki pengetahuan yang mendalam tentang matematika membantu saya } \\
\text { memahami topik yang lebih kompleks dalam bidang studi lain. }\end{array}$ \\
\hline 7 & Pernah mengalami kesulitan saat belajar matematika adalah hal yang wajar \\
\hline
\end{tabular}




\begin{tabular}{|c|l|}
\cline { 2 - 3 } \multicolumn{1}{c|}{} & $\begin{array}{l}\text { Seorang matematikawan yang baik pernah mengalami kesulitan ketika } \\
\text { memecahkan masalah matematis. }\end{array}$ \\
\cline { 2 - 3 } & $\begin{array}{l}\text { Saat belajar matematika, saya akan berusaha keras ketika menghadapi masalah } \\
\text { matematis yang sukar. }\end{array}$ \\
\hline \multirow{5}{*}{8} & Matematika merupakan sesuatu yang sangat penting untuk masa depan saya \\
\cline { 2 - 3 } & $\begin{array}{l}\text { Pengetahuan matematika memiliki peranan yang sangat besar dalam usaha saya } \\
\text { untuk menggapai cita-cita yang saya impikan. }\end{array}$ \\
\hline \multirow{3}{*}{9} & $\begin{array}{l}\text { Mendapat hasil yang salah merupakan hal yang saya perlukan supaya pandai } \\
\text { dalam matematika. }\end{array}$ \\
\cline { 2 - 3 } & $\begin{array}{l}\text { Ketika saya mengalami hambatan ketika memecahkan masalah matematika, saya } \\
\text { langsung mencari/meminta bantuan dari orang lain. }\end{array}$ \\
\hline
\end{tabular}

Berdasarkan tabel 4.7. di atas, maka dapat disusun indikator pembentuk resiliensi matematis berdasarkan faktor dan variabel yang ada. Faktor 1 dijadikan sebagai indikator pertama resiliensi matematis. Indikator pertama resiliensi matematis yang terbentuk disusun oleh 7 variabel. Dengan memperhatikan setiap statement yang ada pada variabel pembentuk tersebut, peneliti merumuskan indikator pertama resiliensi matematis yaitu memiliki kemauan untuk mempelajari dan menguasai matematika.

Faktor 2 dijadikan sebagai indikator kedua resiliensi matematis. Indikator kedua resiliensi matematis yang terbentuk disusun oleh 5 variabel. Dengan memperhatikan setiap statement yang ada pada variabel pembentuk tersebut, peneliti merumuskan indikator kedua resiliensi matematis yaitu menyadari pentingnya mempelajari dan menguasai matematika. Faktor 3 dijadikan sebagai indikator ketiga resiliensi matematis. Indikator ketiga resiliensi matematis yang terbentuk disusun oleh 5 variabel. Dengan memperhatikan setiap statement yang ada pada variabel pembentuk tersebut, peneliti merumuskan indikator ketiga resiliensi matematis yaitu memiliki keyakinan diri sanggup untuk mempelajari dan menguasai matematika.

Faktor 4 dijadikan sebagai indikator keempat resiliensi matematis. Indikator keempat resiliensi matematis yang terbentuk disusun oleh 4 variabel. Dengan memperhatikan setiap statement yang ada pada variabel pembentuk tersebut, peneliti merumuskan indikator keempat resiliensi matematis yaitu menyadari keterbatasan yang dimiliki dalam mempelajari dan menguasai matematika. Faktor 5 dijadikan sebagai indikator kelima resiliensi matematis. Indikator kelima resiliensi matematis yang terbentuk disusun oleh 3 variabel. Dengan memperhatikan setiap statement yang ada pada variabel pembentuk tersebut, peneliti merumuskan indikator kelima resiliensi matematis yaitu menyadari kemungkinan gagal dalam upaya mempelajari dan menguasai matematika.

Faktor 6 dijadikan sebagai indikator keenam resiliensi matematis. Indikator keenam resiliensi matematis yang terbentuk disusun oleh 2 variabel. Dengan memperhatikan setiap statement yang ada pada variabel pembentuk tersebut, peneliti merumuskan indikator keenam resiliensi matematis yaitu menyadari bahwa pengetahuan matematika berguna ketika mempelajari ilmu atau topik selain matematika. Faktor 7 dijadikan sebagai indikator ketujuh resiliensi matematis. Indikator ketujuh resiliensi matematis yang terbentuk disusun oleh 3 variabel. Dengan memperhatikan setiap statement yang ada pada variabel pembentuk tersebut, peneliti merumuskan indikator ketujuh resiliensi matematis yaitu mampu mengatasi kesulitan yang muncul dalam upaya mempelajari dan menguasai matematika.

Faktor 8 dan Faktor 9 masing-masing dijadikan sebagai indikator kedelapan dan kesembilan resiliensi matematis, dimana masing-masing disusun oleh 2 variabel. Dengan memperhatikan setiap statement yang ada pada variabel pembentuk tersebut, peneliti merumuskan indikator kedelapan dan kesembilan resiliensi matematis yaitu menyadari bahwa pengetahuan matematika berperan penting di masa depan dan mengetahui hal-hal yang dibutuhkan dalam upaya mempelajari dan menguasai matematika. 
Dengan demikian maka tersusunlah indikator pembentuk Resiliensi Matematis pada mahasiswa program studi pendidikan matematika yang terdiri dari 9 (Sembilan) indikator. Seluruh indikator tersebut mampu menjelaskan atau menggambarkan bagaimana kemampuan resiliensi matematis yang dimiliki oleh para mahasiswa calon guru matematika. Dengan terbentuknya indikator pembentuk resiliensi matematis tersebut, dapat dilakukan analisis kemampuan resiliensi matematis dan juga pengembangan pembelajaran untuk meningkatkan kemampuan resiliensi matematis pada mahasiswa prodi pendidikan matematika.

\section{Kesimpulan}

Berdasarkan hasil penelitian di atas, dapat disimpulkan bahwa indikator pembentuk Resiliensi Matematis pada mahasiswa prodi pendidikan matematika terdiri dari 9 indikator, yaitu:

1. memiliki kemauan untuk mempelajari dan menguasai matematika.

2. menyadari pentingnya mempelajari dan menguasai matematika.

3. memiliki keyakinan diri sanggup untuk mempelajari dan menguasai matematika.

4. menyadari keterbatasan yang dimiliki dalam mempelajari dan menguasai matematika.

5. menyadari kemungkinan gagal dalam upaya mempelajari dan menguasai matematika.

6. menyadari bahwa pengetahuan matematika berguna ketika mempelajari ilmu atau topik selain matematika.

7. mampu mengatasi kesulitan yang muncul dalam upaya mempelajari dan menguasai matematika.

8. menyadari bahwa pengetahuan matematika berperan penting di masa depan

9. mengetahui hal-hal yang dibutuhkan dalam upaya mempelajari dan menguasai matematika.

\section{Referensi}

Anderson, L., Krathwoll, D., Airasian, P., Cruichshank, K., Mayer, E., Pintrich, P., Raht, J., and Wittrock, M. 2001. A Taxonomy for Learning, Teaching, and Assessing. New York: Addison Wesley Longman, Inc.

Boekarts, M.; Pintrick, P.; Zeidner, M. (2000). Handbook of Self-Regulation. California: Elseiver Academic Press

Glantz, M. \& Johnson, J. (2002). Resilience and development positive life adaptation. USA: Kluwer Academic Publisher

Gondall, J., Johnston-Wilder, S. (2015). Overcoming Mathematical Helpessness and Developing Mathematical Resilience in Parents: An Illustrative Case Study. Creative Education, 6, 526535

Hutauruk, A.JB. and Priatna, N. (2017) Mathematical Resilience of Mathematics Education Students. J. Phys.: Conf. Ser. 895012067

Johnson-Wilder,S., Lee,C. (2010a). Mathematical Resilience. Mathematics Teaching: 218,38-41

Johnson-Wilder,S., Lee,C. (2010b) Developing Mathematical Rsilience. BERA Annual Conference 2010. University of Marwick.

Johnson-Wilder,S., Lee,C. (2011) The Pupil's Voice Creating Mathematically Resilient Community of Learners. Congress of European Society for Research in Mathematics Education 2011. 
Johnston-Wilder, S., Lee, C., Garton, L., Goodlad, S., \& Brindley, J. (2013b). Developing Coaches for Mathematical Resilience. ICERI 2013: 6th International Conference on Education, Research and Innovation, Seville, 18-20 November 2013.

Johnson-Wilder,S., Lee,C., Garton, E. and Brindley, J. (2014) Developing Coaches for Mathematical Reilience. Seville: ICERI 2014.

Johnson-Wilder,S., Brindley, J., and Dent, P. 2014. Survey of Mathematics Anxiety and Mathematical Resilience Among Existing Apprentices. Prepared for The Gatsby Charitable Foundation, with reference to Grant GAT3358/DSS. Coventry: Universuty of Marwick.

Johnson-Wilder,S., Lee,C., Brindley, J., and Garton, E. (2015) Developing Peer Coaching for Mathematical Reilience in Post-16 Students Who Are Encountering Mathematics in Other Subject. Seville: ICERI 2015

Johnson-Wilder,S., Lee,C. (2015) Developing Mathematical Resilience in School-Students Who Have Experienced Repeated Failure. Seville: ICERI 2015

Kirkley, J. 2003. Principles for Teaching Problem Solving. Indiana: Plato Learning Inc.

Kooken, J., Welsh, M., McCoach, D., Johnston-Wilder, S., Lee, C. (2013). Mathematics Resilience Scale. Storrs, CT: University of Connecticut.

Kooken, J., Welsh, M., McCoach, D., Johnston-Wilder, S., Lee, C. (2015). Development and Validation of the Mathematical Resilience Scale. Measurement and Evaluation in Counseling and Development 2016, Vol. 49(3) 217-242

Lee, C. and Johnston-Wilder, S. (2013). Learning Mathematics - Letting the Pupils Have Their Say'. Educational Studies in Mathematics, vol. 83, no. 2, pp. 163-80.

Lugalia, M., Johnson-Wilder,S., and Goodal, J. 2015. Using ICT and Dialog Teaching: Impact on Mathematical Resilience and Attainment in Algebra of A Kenyan School Year Group. Edulearn15 Proceedings, pp. 5069-5078

Maddi, S. \& Khoshaba, D. (2005). Resilience at work: How to succed no matter what life throws at you. USA: American Management Association.

Mar'at,S..2010.Psikologi Perkembangan. Bandung:PT.Remaja Rosdakarya

National Council of Teachers of Mathematics. 2000. Principles and Standards for School Mathematics. Reston: National Council of Teacher of Mathematics.

National Research Council. 2001. Adding it Up: Helping Children Learning Mathematics. In J.Kilpatrick, J.Swafford \& B.Findell (eds). Washington DC: National Academy Press

Norman, E. (2000). Resiliency enhancement: Putting the strength perspective into social work practice. New York: Columbia University Press.

Padmavathy, R.D., and Mareesh, K. (2013). Effectiveness Of Problem Based Learning In Mathematics. International Multidiciplinary e-Journal. Vol 2(1)

Peatfield, N. (2015). Affective Aspect of Mathematical Resilience. Adams G.(Ed.) Proceedings of the British Society for Research into Learning Mathematics 35(2) 
Reivich, K \& Shatte, A. (2002). The resilience factor: 7 skills for overcoming life's inevitable obstacles. New York : Random House, Inc.

Schoon, I. (2006). Risk \& resilience: Adaptations in changing times. Cambridge University Press.

Siebert, A. (2005). The resilience advantage: Master change, thrive under pressure, and bounce back from setbacks. California: Berrett-Koehler Publishers, Inc.

Thornton, S., and Statton, J. 2012. Developing Mathematical Resilience among Aboriginal Students. In J. Dindyal, L. P. Cheng \& S. F. Ng (Eds.), Mathematics education: Expanding horizons (Proceedings of the 35th annual conference of the Mathematics Education Research Group of Australasia). Singapore: MERGA

Waxman, H. C., Gray, J. P., and Padron, Y. N. (2003). Review of Research on Educational Resilience. Berkeley, CA: UC Center for Research on Education, Diversity and Excellence.

https://escholarship.org/uc/item/7x695885

Zolkoski ,S.M dan Bullock ,L. M. 2012.Reilience In Children and Youth. University of North Texas.Vol.34 